\title{
Evaluation of Turmeric (Curcuma longa L.) Genotypes for Growth, Yield and Quality under Rainfed Condition of Arunachal Pradesh, India
}

\author{
P.S. Mariam Anal*
}

Department of Vegetable Science, College of Horticulture and Forestry, Central Agricultural University, Pasighat, Arunachal Pradesh, India

*Corresponding author

\begin{abstract}
A B S T R A C T
\section{Keywords}

Turmeric,

Genotypes, Growth,

Yield, Curcumin,

Essential oil and oleoresin

Article Info

Accepted:

04 August 2019

Available Online:

10 September 2019

Field experiments were conducted in randomized block design with three replications at the Horticulture Experimental Farm, College of Horticulture and Forestry, Central Agricultural University, Pasighat, Arunachal Pradesh for four seasons starting from the year 2013-14 and ending in 2016-17. Total 12genotypes were taken for study including one local and one national check. Observations were recorded for various growth, yield and quality characters such as plant height $(\mathrm{cm})$, number of tillers per plant, number of days to maturity, rhizome yield per plant $(\mathrm{kg})$, rhizome yield $(\mathrm{t} / \mathrm{ha})$, dry recovery $(\%)$, curcumin content $(\%)$, essential oil $(\%)$ and oleoresin content $(\%)$. The data were analyzed as per statistical procedure. In general during the four years of study the result revealed significant variation for all the characters considered. Taller plant height was recorded in genotype NDH-98, Megha Turmeric-1 and NDH 8. Higher number of tillers per plant was associated with the genotypes NDH-98, NDH-79, PTS-12, TCP-64, Acc.-48 and the local check Megha Turmeric-1. The genotype NDH- 98 recorded the highest rhizome yield per plant and per hectare and it was significantly superior to all the other genotypes including the National Check Prathibha and Local check Megha Turmeric-1 with few exceptions in some years. The significantly higher dry recovery percentage of turmeric was recorded in genotype NDH-8 while the lowest was exhibited in genotype PTS-8 with some exception over the years. Higher curcumin content was recorded in genotype PTS-8, Acc.-48 (IISR Pragati), SLP-389/1, NDH-8, NDH-79, NDH-98, PTS-12 including local check Megha Turmeric 1. The variation in essential oil among the genotypes was found to be not significant. The maximum oleoresin content was recorded in genotype NDH-8 which remained at par to Acc.-79, SLP-389/1, NDH-79 and PTS-8 respectively.
\end{abstract}

\section{Introduction}

Turmeric (Curcuma longa L.) is one of the important spice crop grown in India since times immemorial. It is widely used in ceremonies and religious functions. It is an erect, herbaceous perennial belonging to the family Zingiberaceae and native to South East Asia (Chickarmane et al., 2003).Turmeric is valued for its deep yellow colour and pungent aromatic flavour due to the presence of colouring matter 'curcumin' and a volatile oil 'termerol'. It is also an important condiment which finds a unique place in culinary arts and 
as colouring agent in textile, food, confectionary, cosmetics and drug industries, of late in the preparation of anti-cancer medicines.

Turmeric is a tropical crop and needs a warm and humid climate with an optimum temperature of 20 to $30^{\circ} \mathrm{C}$ for normal growth and satisfactory production. It thrives best on sandy loam or alluvial, loose, friable and fertile soil rich in organic matter status and having a $\mathrm{pH}$ range of 5.0 to 7.5. Alkaline soil is not suitable for its cultivation. The crop cannot withstand water logging. It grows at all places ranging from sea level to an altitude of $1200 \mathrm{~m}$ above mean sea level. As a rainfed crop turmeric needs a well distributed annual rainfall of 250 to $400 \mathrm{~cm}$ for successful production.

India is the major producer of turmeric and $4^{\text {th }}$ most important spice crop of India. In India it is being cultivated in an area of 1,93,400 ha with an annual production of 10,52,100 MT and productivity of $5.44 \mathrm{MT} / \mathrm{ha}$. In Arunachal Pradesh it is raise in an area of 800 ha with an annual production of 3800 tonnes and productivity of $4.75 \mathrm{t} / \mathrm{ha}$ (Anon., 2017). The average productivity of the crop is however low in the state as against the National yield average. Lack of suitable cultivar for a particular agro-climatic condition is one of the reasons for low productivity. Several studies revealed existence of significant variability in turmeric genotypes with regard to growth, yield and quality attributes when grown under different agro climatic conditions.

The performance of any crop or variety largely depends upon its genetic makeup. Further, the performance of the crop depends upon climatic conditions of the region under which they are grown. As a result, genotypes which perform well in one region may not perform well in other regions of varying climatic conditions. Hence, it is very much necessary to collect and evaluate all the available genotypes in order to select suitable and high yielding genotypes for a given agroclimatic condition. Considering the importance of turmeric, research on this crop is very much necessary to find out the suitability of different genotypes for a particular region. Though wide genetic variability exists in the crop with respect to the growth and yield but not much work seems to have been done on crop improvement through the simple selection of the high yielding genotypes (Singh and Prasad, 2006). Keeping in view the above fact the present investigation was carried out to find a suitable genotype.

\section{Materials and Methods}

Twelve genotypes of turmeric including one national check and local check (Acc.-48,Acc.79, SLP-389/1, NDH-8, NDH 79, NDH-98, TCP-64, PTS-12, PTS-8, PTS-55, Prathibha (NC) and Megha Turmeric-1 (LC)) were grown in randomized block design (RBD) with three replications at Vegetable Research Farm, College of Horticulture and Forestry, Central Agricultural University, Pasighat, Arunachal Pradesh for four seasons starting from the year 2013-14 and ending in 2016-17. The soil of the experimental field was sandy loam in texture with a soil $\mathrm{pH}$ of 5.0-5.5, high in organic carbon $(1.5 \%)$, medium in available nitrogen $(327 \mathrm{~kg} / \mathrm{ha})$, low in available $\mathrm{P}_{2} \mathrm{O}_{5}(35$ $\mathrm{kg} / \mathrm{ha})$ and high in available $\mathrm{K}_{2} \mathrm{O}$ (360 $\mathrm{kg} / \mathrm{ha}$ ).Geographically it is located at latitude of $28^{\circ} 06^{\prime} \mathrm{N}$, longitude $93^{\circ} 32^{\prime} \mathrm{E}$ and altitude of $153 \mathrm{~m}$ MSL, hailing to the subtropical hot humid climatic condition and is one of the major production belts of turmeric. Healthy rhizomes having 2-3 buds were planted at 30 $\mathrm{cm}$ apart in rows keeping $25 \mathrm{~cm}$ plant to plant distance. The entire recommended package of practices was followed to raise a good crop. Five plants were randomly selected from each plot to record observations on quantitative 
characters like plant height $(\mathrm{cm})$ and number of tillers per clump. The days to maturity, rhizomes yield (t/ha) and dry recovery were observed and workout. The qualitative characters like curcumin (\%), essential oil (\%) and oleoresin content were also recorded. The curcumin content was estimated as per the methods of ASTA (Anon., 1968) proposed by Manjunath et al., (1991).

Curcumin
$($ per cent $)=$$\quad$ content $\frac{\text { OD value } \times 125 \times 0.0025}{0.42 \times 0.1 \times 1}$

The oleoresin content was calculated using the following formula and expressed as per cent (AOAC, 1975).

Oleoresin content $($ per cent $)=$ (air dry)

$$
\frac{\mathrm{W} 2-\mathrm{W} 1}{10} \times 100
$$

Where,

$\mathrm{W} 1$ = weight of empty beaker

$\mathrm{W} 2$ = weight of beaker with air dried oleoresin

The essential oil content was estimated as per the methods suggested by ASTA (Anon, 1968). The volume was measured and the oil content was calculated as

$$
\begin{array}{lc}
\text { Essential oil content } & \begin{array}{c}
\text { Volume of } \\
\text { oil }(\mathrm{ml})
\end{array} \\
\cline { 2 - 2 }(\text { per cent })= & \begin{array}{c}
\text { Weight of } \\
\text { sample }(\mathrm{g})
\end{array}
\end{array}
$$

The mean values were subjected to statistical analysis of data for each character as per method given by Panse and Shukhatme (1978).

\section{Results and Discussion}

Ten turmeric genotypes namely Acc.-48, Acc.-79, SLP-389/1, NDH-8, NDH-79, NDH98, TCP-64, PTS-12, PTS-8, PTS-55were evaluated in Randomized Block Design with three replications along with National Check,
Prathibha and Local Check, Megha Turmeric1 during four years starting from 2013-14 to 2016-17 at Pasighat, Arunachal Pradesh.

\section{Growth characters}

The result revealed that signifcant variation in growth parameters were observed among the different genotypes during the four years of study and in the pooled mean. The tallest plant height was recorded in genotype NDH-98 $(103.95 \mathrm{~cm})$ which was statistically at par with Megha Turmeric-1 (94.43 cm) and NDH-8 $(93.02 \mathrm{~cm})$ in all the years of investigation and pooled mean with an exception in 2016-17. Though, the shortest stature of plant was observed in PTS-55 (85.70 cm) in 2013-14, Acc.-48 $(86.00 \mathrm{~cm})$ in $2014-15$, PTS-8 (60.33 $\mathrm{cm})$ in $2015-16$ and SLP-389/1 $(64.00 \mathrm{~cm})$ in 2016-17 and in $(79.88 \mathrm{~cm})$ pooled mean, however, they were at par to each other. The variation in plant height might be attributed to genetic variation among the genotypes. Dhatt et al., (2008), Singh et al., (2013) and Prasath et al., (2016) also reported the differences in plant height with different genotypes. Maximum number of tillers per plant was recorded in NDH-98 in all the years (4.73, 4.07 and 4.30) of study and pooled mean (4.28) except in 2013-14 where NDH-79 (4.13) exhibited the highest number of tillers per plant but remained at par to each other in all the occasions. Again these genotypes (NDH-98, NDH-79) did not differ significantly with PTS-12, TCP-64, Acc.-48 and Megha Turmeric-1 in respect of number of tillers per plant with few exceptions. The minimum number of tillers per plant was associated with the genotype Acc.-79 (2.87, $2.87,2.73,2.83$ and 2.83) in all the four years of investigation as well as pooled mean. Similar variations in these characters among the genotypes were reported by earlier workers in turmeric and ginger under different agro-climatic conditions (Babu et al., 1993, Dhatt et al., 2008 and Rajyalakshmi and Umajyothi, 2014) (Table 1). 
Table.1 Plant height, number of tillers/plant and number of days to maturity as influence by different genotypes of turmeric

\begin{tabular}{|c|c|c|c|c|c|c|c|c|c|c|c|c|c|c|c|}
\hline \multirow[t]{2}{*}{ Genotype } & \multicolumn{5}{|c|}{\begin{tabular}{|c|} 
Plant height $(\mathrm{cm})$ \\
\end{tabular}} & \multicolumn{5}{|c|}{ No. of tillers/plant } & \multicolumn{5}{|c|}{ No. of days to maturity } \\
\hline & 2013-14 & 2014-15 & 2015-16 & 2016-17 & $\begin{array}{c}\text { Pool } \\
\text { mean of } 4 \\
\text { years }\end{array}$ & 2013-14 & 2014-15 & 2015-16 & 2016-17 & $\begin{array}{c}\text { Pool } \\
\text { mean of } 4 \\
\text { years }\end{array}$ & 2013-14 & 2014-15 & 2015-16 & 2016-17 & $\begin{array}{c}\text { Pool } \\
\text { mean of } 4 \\
\text { years }\end{array}$ \\
\hline Acc.-48 & 100.27 & 86.00 & 63.33 & 78.33 & 81.98 & 3.93 & 3.53 & 3.33 & 3.47 & 3.57 & 202.07 & 212.33 & 208.00 & 226.00 & 212.10 \\
\hline Acc.-79 & 106.20 & 94.00 & 70.33 & 64.67 & 83.80 & 2.87 & 2.87 & 2.73 & 2.83 & 2.83 & 208.80 & 216.67 & 205.00 & 221.33 & 212.95 \\
\hline SLP-389/1 & 98.53 & 89.67 & 67.33 & 64.00 & 79.88 & 3.60 & 3.40 & 3.07 & 3.17 & 3.31 & 200.93 & 201.73 & 198.00 & 216.00 & 204.17 \\
\hline NDH-8 & 110.73 & 99.00 & 73.67 & 88.67 & 93.02 & 4.07 & 3.73 & 3.27 & 3.43 & 3.63 & 214.60 & 222.80 & 208.67 & 229.00 & 218.77 \\
\hline NDH-79 & 103.17 & 96.23 & 60.67 & 83.67 & 85.94 & 4.13 & 4.33 & 3.60 & 3.67 & 3.93 & 207.93 & 213.33 & 206.00 & 224.33 & 212.90 \\
\hline NDH-98 & 115.80 & 115.00 & 81.67 & 103.33 & 103.95 & 4.00 & 4.73 & 4.07 & 4.30 & 4.28 & 210.00 & 218.27 & 208.00 & 230.00 & 216.57 \\
\hline ТСР-64 & 90.50 & 88.33 & 73.33 & 86.00 & 84.54 & 3.87 & 3.80 & 3.40 & 3.73 & 3.70 & 191.17 & 215.00 & 200.00 & 218.00 & 206.04 \\
\hline PTS-12 & 98.03 & 87.00 & 63.00 & 79.33 & 81.84 & 3.87 & 3.67 & 3.33 & 3.47 & 3.59 & 202.93 & 217.67 & 203.00 & 221.33 & 211.23 \\
\hline PTS-8 & 107.37 & 94.67 & 60.33 & 72.33 & 83.68 & 3.40 & 3.13 & 2.87 & 3.13 & 3.13 & 202.53 & 216.33 & 188.67 & 218.00 & 206.38 \\
\hline PTS-55 & 85.70 & 96.00 & 67.33 & 72.33 & 80.34 & 3.20 & 3.60 & 3.07 & 3.20 & 3.27 & 187.27 & 215.00 & 196.67 & 221.33 & 205.07 \\
\hline $\begin{array}{l}\text { Prathibha } \\
\text { (NC) }\end{array}$ & 100.17 & 93.33 & 70.00 & 74.33 & 84.46 & 3.33 & 3.20 & 3.00 & 3.17 & 3.18 & 206.33 & 215.00 & 201.33 & 219.33 & 210.50 \\
\hline $\begin{array}{c}\text { Megha } \\
\text { Turmeric- } \\
1 \text { (LC) }\end{array}$ & 101.03 & 109.33 & 75.67 & 91.67 & 94.43 & 3.93 & 3.73 & 3.33 & 3.50 & 3.62 & 209.67 & 215.00 & 197.33 & 221.33 & 210.83 \\
\hline SEm \pm & 5.29 & 5.53 & 3.8 & 3.59 & 4.55 & 0.26 & 0.31 & 0.26 & 0.19 & 0.25 & 4.08 & 3.15 & 4.57 & 1.45 & 3.87 \\
\hline CD at $5 \%$ & 15.52 & 16.23 & 11.36 & 12.89 & 14.00 & 0.76 & 0.92 & 0.76 & 0.72 & 0.79 & 14.06 & NS & 15.6 & 5.45 & 11.70 \\
\hline CV \% & 9.03 & 10.01 & 9.74 & 9.53 & 9.58 & 12.13 & 14.87 & 13.73 & 12.34 & 13.26 & 4.79 & 5.85 & 5.32 & 1.52 & 3.98 \\
\hline
\end{tabular}


Table.2 Yield and yield attributes of turmeric as influence by different genotypes

\begin{tabular}{|c|c|c|c|c|c|c|c|c|c|c|c|c|c|c|c|}
\hline \multirow[t]{2}{*}{ Genotype } & \multicolumn{5}{|c|}{ Rhizome Yield/plant (kg) } & \multicolumn{5}{|c|}{ Rhizome yield (t/ha) } & \multicolumn{5}{|c|}{ Dry recovery $(\%)$} \\
\hline & 2013-14 & $42014-15$ & 2015-16 & 2016-17 & $\begin{array}{l}7 \text { Pool mean } \\
\text { of } 4 \text { years }\end{array}$ & 2013-14 & 2014-15 & 2015-16 & 2016-17 & $\begin{array}{l}7 \text { Pool mean } \\
\text { of } 4 \text { years }\end{array}$ & 2013-14 & $42014-15$ & $2015-16$ & 2016-17 & $\begin{array}{l}\text { Pool mean } \\
\text { of } 4 \text { years }\end{array}$ \\
\hline Acc. -48 & 0.18 & 0.18 & 0.09 & 0.18 & 0.16 & 24.15 & 23.64 & 12.49 & 22.00 & 20.57 & 21.23 & 21.13 & 21.30 & 23.47 & 21.78 \\
\hline Acc.-79 & 0.17 & 0.18 & 0.08 & 0.15 & 0.15 & 23.22 & 23.53 & 10.66 & 17.54 & 18.74 & 20.95 & 21.57 & 21.60 & 20.13 & 21.06 \\
\hline SLP-389/1 & 0.14 & 0.15 & 0.05 & 0.11 & 0.11 & 19.04 & 20.20 & 7.22 & 13.55 & 15.00 & 21.32 & 21.17 & 21.47 & 22.67 & 21.66 \\
\hline NDH-8 & 0.25 & 0.25 & 0.06 & 0.12 & 0.17 & 32.76 & 32.97 & 8.62 & 14.65 & 22.25 & 32.22 & 21.80 & 21.57 & 22.67 & 24.57 \\
\hline NDH-79 & 0.27 & 0.27 & 0.07 & 0.12 & 0.18 & 35.50 & 35.74 & 8.77 & 14.71 & 23.68 & 20.14 & 20.63 & 21.30 & 21.87 & 20.99 \\
\hline NDH-98 & 0.27 & 0.27 & 0.17 & 0.23 & 0.24 & 35.63 & 36.41 & 22.64 & 28.3 & 30.75 & 21.01 & 20.60 & 21.13 & 19.93 & 20.67 \\
\hline ТСР-64 & 0.11 & 0.14 & 0.05 & 0.09 & 0.10 & 15.25 & 18.35 & 6.55 & 11.43 & 12.90 & 21.25 & 19.73 & 20.93 & 22.60 & 21.13 \\
\hline PTS-12 & 0.18 & 0.18 & 0.06 & 0.12 & 0.14 & 23.61 & 24.20 & 7.34 & 14.99 & 17.54 & 19.89 & 20.03 & 20.80 & 23.47 & 21.05 \\
\hline PTS-8 & 0.14 & 0.15 & 0.05 & 0.11 & 0.11 & 18.90 & 19.31 & 6.77 & 13.88 & 14.72 & 18.90 & 19.83 & 20.60 & 22.20 & 20.38 \\
\hline PTS-55 & 0.21 & 0.21 & 0.08 & 0.15 & 0.16 & 28.45 & 27.75 & 10.10 & 16.65 & 20.74 & 20.85 & 21.57 & 21.30 & 18.93 & 20.66 \\
\hline $\begin{array}{l}\text { Prathibha } \\
\text { (NC) }\end{array}$ & 0.16 & 0.16 & 0.07 & 0.13 & 0.13 & 21.45 & 21.53 & 9.32 & 15.54 & 16.96 & 21.17 & 21.77 & 21.20 & 23.53 & 21.92 \\
\hline $\begin{array}{c}\text { Megha } \\
\text { Turmeric-1 } \\
\text { (LC) }\end{array}$ & 0.17 & 0.21 & 0.09 & 0.2 & 0.17 & 22.81 & 27.75 & 11.54 & 23.86 & 21.49 & 21.73 & 21 & 21.13 & 21.53 & 21.35 \\
\hline SEm \pm & 0.01 & 0.02 & 0.01 & 0.01 & 0.01 & 1.92 & 2.52 & 1.21 & 1.14 & 1.69 & 0.58 & 0.49 & 0.36 & 0.85 & 0.57 \\
\hline CD at $5 \%$ & 0.04 & 0.06 & 0.03 & 0.04 & 0.04 & 5.62 & 7.39 & 3.54 & 4.11 & 5.16 & 1.71 & 1.42 & NS & 3.05 & 1.81 \\
\hline CV \% & 13.24 & 16.81 & 20.57 & 16.01 & 16.65 & 13.24 & 16.81 & 20.57 & 14.05 & 16.16 & 4.83 & 4.02 & 2.92 & 8.23 & 5.00 \\
\hline
\end{tabular}


Table.3 Quality of turmeric as influence by different genotypes

\begin{tabular}{|c|c|c|c|}
\hline Genotype & Curcumin (\%) & Essential oil (\%) & Oleoresin (\%) \\
\hline Acc.-48 & 6.20 & 7.00 & 11.12 \\
\hline Acc.-79 & 5.70 & 6.50 & 12.81 \\
\hline SLP-389/1 & 6.30 & 6.80 & 12.50 \\
\hline NDH-8 & 6.40 & 7.40 & 12.91 \\
\hline NDH-79 & 6.10 & 7.30 & 12.36 \\
\hline NDH-98 & 6.00 & 6.90 & 11.52 \\
\hline TCP-64 & 5.80 & 6.70 & 11.25 \\
\hline PTS-12 & 6.10 & 6.70 & 11.97 \\
\hline PTS-8 & 6.50 & 7.30 & 12.75 \\
\hline PTS-55 & 5.70 & 6.90 & 11.36 \\
\hline Prathibha (NC) & 5.40 & 6.50 & 12.23 \\
\hline Megha Turmeric-1 & 6.20 & 6.90 & 11.46 \\
\hline (LC) & & & 0.16 \\
\hline SEm \pm & 0.15 & 0.34 & 0.58 \\
\hline CD at 5\% & 0.52 & NS & 4.94 \\
\hline CV \% & 5.09 & 5.91 & \\
\hline & & & \\
\hline
\end{tabular}

The number of days taken from planting to harvesting differed significantly among turmeric genotypes. The genotype SLP-389/1 took minimum days (204.17) for maturation while NDH-8 recorded maximum days (218.77) for crop maturation followed by NDH-98, Acc.-79 and Acc-48. The differences in crop maturation among the different genotypes of turmeric were also reported by Hrideek et al., (2006), Singh and Prasad (2006) and Singh et al., (2013).

\section{Yield attributes and yield}

A perusal of Table 2 showed significant variation in rhizome yield among the genotypes. The genotype NDH-98 recorded the highest rhizome yield per plant $(0.27,0.27$, $0.17,0.23$ and $0.24 \mathrm{~kg}$ ) in all the four years of study as well as in pooled mean and it was significantly superior to all the other genotypes in all the years with exception in 2013-14 and 2014-15 where it did not differ significantly with NDH-8 and NDH-79 respectively. The yield per hectare also followed the similar trend as that of rhizome yield per plant with NDH-98 $(35.63,36.41$, $22.64,28.30$ and $30.75 \mathrm{t} / \mathrm{ha}$ ) recording the maximum rhizome yield, which was significantly superior over National Check Pratibha and Local check Megha Turmeric-1. Better growth and higher yield component 
contributed positively for the higher rhizome yield in this genotype. The lowest rhizome yield was recorded in genotype TCP-64 $(15.25,18.35,6.55,11.43$ and $12.90 \mathrm{t} / \mathrm{ha})$ over the years of investigation and pooled mean. Pirjade et al., (2007), Chaturvedi et al., (2010), Negi et al., (2012) and Singh (2013) reported wide variability for rhizome yield among genotypes of turmeric. A significant difference in dry recovery of turmeric was observed among the genotypes in all the years of study with an exception in 2015-16. The significantly higher dry recovery percentage of turmeric was recorded in genotype NDH-8 $(24.57 \%)$ in four years pooled mean while the lowest was exhibited in genotype PTS-8 (20.38 \%) with some exception over the years.

\section{Quality parameters}

The highest curcumin content was recorded in genotype PTS-8 (6.5\%) which remained at par to Acc.-48 (IISR Pragati), SLP-389/1, NDH-8, NDH-79, NDH-98, PTS-12 and local check Megha Turmeric-1 but significantly superior to rest of the other genotypes (Table 3 ). The variation in curcumin content among different cultivars could be related to the genetic character of the cultivars. The differences in curcumin content among the different genotypes was reported earlier by Rao et al., (2006), Deshmukh et al., (2009), Kamble et al., (2011) and Singh et al., (2013). Though variation in essential oil among the genotypes was observed with maximum recording in genotype NDH-8, however, the differences were found to be not significant. The maximum oleoresin content was recorded in genotype NDH-8 (12.91\%) which remained at par to Acc.-79, SLP-389/1, NDH79 and PTS-8 but significantly higher to other genotypes. From the present study, it can be concluded that genotypes NDH-98 and NDH8 performed better in terms of yield and quality respectively in Arunachal Pradesh.

\section{References}

A.O.A.C. (1975).Official methods of analysis. Association of official Agricultural Chemists, Washington, D.C. $12^{\text {th }} \mathrm{Edn}$.

Anonymous (1968). Official Analytical Methods.2nd Edn. American Spice Trade Association, 38: 9-10.

Anonymous (2017). Horticultural Statistics at a Glance. Govt. of India. Ministry of Agri. and Farmers Welfare, Deptt. of Agri., Cooperation and Farmers welfare, Horti. Statistics Div.

Babu, N.K., Sasikumar, B., Ratnambal, M.J., George, J.K and Ravindran, P.N. (1993). Genetic variability in turmeric (Curcuma longa L.). Indian J. Genet. Plant Breed. 53: 91-93.

Chaturvedi, O. P., Dwivedi, A.K. and Tripathi, S.M., (2010). Varietal performance of turmeric. The Asian $J$. Hort., 4(2): 517-518.

Chickarmane, S., Rehse, T. and Prayer, K.M (2003). Tracing the cultural and botanical origins of turmeric (Curcuma longa L.). Poster. Botany conf.org.in

Deshmukh, N.A., Gondane, S.U., Ingole, P.S. and Patil, S.R (2009). Performance of different promising cultivars of turmeric under Nagpur condition. J. Soilsand Crops, 19(1): 88-91.

Dhatt, A.S., Sadhna, A., Neena, C.,Sidhu, A.S and Naveen G. (2008). Evaluation of elite turmeric (Curcuma longa L.) clones for growth, yield and quality attributes. Indian J. Agric. Sci., 78(7): 589-591.

Hrideek, T.K., Kuruvilla, K.M., B Indianumol, G.P., Menon, P.P., Madhusoodanan, K.J. and Thomas, J. (2006). Performance evaluation of turmeric (Curcuma longa L.) varieties at higher elevation of Western Ghats. $J$. Plantation Crops, 34(3): 178-180.

Kamble, K.J., Ingale, V.M. and 
Kalendhonkar, D.P. (2011). Comparative study of curcumin extraction from turmeric varieties grown in Maharashtra. African J. Food Sci. 5(14): 780-789.

Manjunath, M.M., Sattigeri, V.V and Nagaraj, K.V (1991).Curcumin in turmeric. Spice India, 4(3): 7-9.

Negi, R.S., Baghel, K.S. and Gautham, U.S (2012). Evaluation of turmeric (Curcuma longa L.) varieties for their suitability to Kaymore plateau and Satpura hills agroclimatic zone of Madhya Pradesh. Life Sci., Bull., 9(1): 179-180.

PanseVG, Sukhatme PV (1967) Statistical methods for agricultural workers, Ind Coun Agric Res New Delhi, pp 155

Panse, V.G and Sukhatme, P.V. (1978).Statistical methods for agricultural workers. $3^{\text {rd }}$ edn., ICAR, New Delhi, pp 347.

Pirjade, F.N., Jogdande, N.D., Nandre, D. R., Ghawade, S, M. and Patil, P.A (2007). Varietal performance of turmeric. PlantArchives, 7(1): 363-364.

Prasath, D., Eapen, S.J., and Sasikumar, B. (2016).Performance of turmeric (Curcuma longa) genotypes for yield and root-knot nematode resistance. Indian J. Agric. Sci. 86(9): 1189-1192.
Rajyalakshmi, R. and Umajyothi, K. (2014). Evaluation of ginger (Zingiber officinale Rosc.) varieties in high altitude and tribal zone of Srikakulam district of Andrapradesh. J. Spices and Aromatic Crops, 23(2):258-261.

Rao, A.M., Rao, P.V. and Reddy, Y.N (2006). Growth analysis and curcumin content of long- medium and short duration turmeric (Curcuma longa L.) genotypes. J. Spices and Aromatic crops, 15(1): 42-47.

Singh, A.K (2013). Evaluation of turmeric (Curcuma longa L.) genotypes for yield attributes, yield and reaction to foliar diseases. J. Spices and Aromatic Crops, 22(2): 238-240.

Singh, B.K., Ramakrishna, Y., Deka, B.C., Verma, V.K. and Pathak, K.A. (2013). Varieties and planting dates affect the growth, yield and quality of turmeric (Curcuma longa L.) in mild-tropical environment. Veg. Sci., 40(1): 40-44.

Singh, S.P. and Prasad, R. (2006). Studies on varietal performance of turmeric (Curcuma longa L.). Int. J. Plant Sci., 1(1): 22-23.

Singh, Y., Mittal, $\mathrm{P}$ and Katoch, V. (2003).Genetic variability and heritability in turmeric (Curcuma longa L.). Himachal J. Agri. Res. 29: 31-34.

\section{How to cite this article:}

Mariam Anal, P.S. 2019. Evaluation of Turmeric (Curcuma longa L.) Genotypes for Growth, Yield and Quality under Rainfed Condition of Arunachal Pradesh, India. Int.J.Curr.Microbiol.App.Sci. 8(09): 619-626. doi: https://doi.org/10.20546/ijcmas.2019.809.074 